small aquaria containing about 15 litres, the temperature of the water being kept at $23^{\circ}-25^{\circ} \mathrm{C} .\left(=73^{\circ} \cdot 4-77^{\circ} \mathrm{F}\right.$.).-Comptes Rendus, December 6, 1875, p. 1136.

\title{
Zoological Notes made during a Residence at Scheveningen.
} By M. P. HaRting.

In these Notes we find some particulars as to the membrane of the egg of Cyanea, the otoliths of Cyanea and Chrysaora, the nervous system and organs of the senses of an Encope, and some interesting researches upon the chromatophores of the embryos of Loligo vulgaris. The observations made by M. Harting upon these last organs lead to some results which differ in certain points from those arrived at by Harless, Brücke, and, more recently, F. Boll.

The embryos of Loligo which furnished the Dutch naturalist with the most favourable objects of study were only from 3 to 4 millims. long. In living individuals of this size the body is sufficiently transparent to allow of the employment of transmitted light, and show clearly the relations of the ehromatophores to the tissue surrounding them.

When the chromatophores are in a contracted state, they present the appearance of small, nearly black globules, from 0.020 to 0.030 millim. in diameter, and eonsequently invisible to the naked eye. They are therefore without influence on the ground of the general colour of the animal, which is milk-white. When they extend, the chromatophores begin to show the colour which is proper to them-that is to say, yellow, brownish or reddish yellow, and more or less reddish violet; and their transparency inereases with the degree of expansion at the same time that the colour becomes brighter.

I. Harting did not observe the chromatophores in course of division; he believes that the increase in the number of these organs takes place by the appearance in the clear spaces of new chromatophores which are at first yellow and afterwards pass to other colours. With the exception of a very small number of yellow chromatophores of very small size, which the author regards as being in course of formation, the diameter of these organs in the expanded state varies from $0 \cdot 150$ to $0 \cdot 200$ millim.; so that they have from 7 to 10 times the diameter and from 50 to 100 times the surface of the contracted chromatophores. When the vitality of the animal is still great, the contraction and expansion take place in a very rhythmical manner, and may arrive at the number of ten to twelve changes of state per minute. When life begins to fail in the embryo out of its envelope, the movements slacken; they afterwards cease completely; and when the animal is dead, nearly all the chromatophores remain in a state of expansion. This fact is scarcely explicable in accordance with the views of those naturalists who, like Harless and Boll, assume the existence of contractile fibres of muscular nature inserted in the walls of the chromatophores, and producing expan- 
sion by means of a traction exerted upon these pigment-sacs. Under the old explanation expansion would be the active and contraction the passive phase; and, indeed, a stellate form has been described as the result of the dragging produced upon certain points. M. Harting has never seen this last appearance; he has only sometimes recognized the existence of processes resembling small diverticula.

According to M. Harting, all the chromatophores of the embryos of Loligo are situated immediately beneath the epidermis, in the layer which will afterwards become the dermis, and which then presents the ordinary structure of still amorphous connective tissue. Each of them is placed in a small flattened cavity, in which it can effect its movements of contraction and expansion. Without pronouncing any decided opinion, M. Harting thinks it probable that there is a very delicate parietal membrane. He was unable to ascertain the existence of a nucleus; but this negative observation is not of much value, as F. Boll says expressly that the nucleus is very difficult to distinguish in Loligo.

Although M. Harting did not succeed in recognizing muscular fibres inserted upon the periphery of the chromatophores, he nevertheless ascertained the existence of fibres of another kind, from twelve to twenty of which radiate round each chromatophore. Each of these fibres terminates towards the chromatophore by an inflated part containing an ellipsoidal nucleus. Under a very high power the terminal inflation shows four or five longitudinal striæ, which may be traced into the slender part of the fibre, and which perhaps indicate that the radial fibres are themselves composed of a certain number of much more delicate fibres. M. Harting has never seen these fibres continued into those of a neighbouring chromatophore; but in proportion as they depart from the chromatophore they become paler and paler, and seem to lose themselves in the midst of the surrounding granular tissue. It is nevertheless possible that they may change their level and be continued into the muscular layer. Áccording to M. Harting, these fibres do not unite to form, as Boll supposed, a wall round the chromatophore; they are, on the contrary, isolated and independent of each other. M. Harting's opinion is that the power of expansion and contraction resides in the protoplasmic substance of the chromatophore, and not in the fibres or cells which surround it. He thinks that the fibres are of nervous nature, and that under their influence the chromatophore, by its own activity, executes the movements of which it is the seat. By examples derived from what is observed in the cells of the walls of the heart in the embryo of Loligo, in many Infusoria and Gregarinæ, and in the chromatophores of the chameleon, he shows that analogies are not wanting in favour of this view.-Niederländisches Archiv für Zoologie, vol. ii. 1875; Bibl. Univ., Bull. Sci. December 15, 1875 , p. 432. 


\section{$2 \mathrm{BHL}$ Biodiversity Heritage Library}

Harting, M P. 1876. "Zoological notes made during a residence at Scheveningen." The Annals and magazine of natural history; zoology, botany, and geology 17, 174-175. https://doi.org/10.1080/00222937608681926.

View This Item Online: https://www.biodiversitylibrary.org/item/63494

DOI: https://doi.org/10.1080/00222937608681926

Permalink: https://www.biodiversitylibrary.org/partpdf/59544

\section{Holding Institution}

University of Toronto - Gerstein Science Information Centre

\section{Sponsored by}

University of Toronto

\section{Copyright \& Reuse}

Copyright Status: NOT_IN_COPYRIGHT

This document was created from content at the Biodiversity Heritage Library, the world's largest open access digital library for biodiversity literature and archives. Visit BHL at https://www.biodiversitylibrary.org. 